原 著

\title{
Acute Encephalopathy Following Exanthem Subitum Caused by Human Herpesvirus- 6
}

\author{
Takami SATO ${ }^{1)}$, Toshiro INOUE ${ }^{21}$, Masato KAJIWARA ${ }^{2)}$, Chiaki MIYAZAKI ${ }^{3)}$, \\ Koichi KUSUNOKI ${ }^{3)}$ and Kohji UEDA ${ }^{3)}$ \\ ${ }^{1)}$ Department of Pediatrics, Jichi Medical School, Tochigi \\ ${ }^{2}$ Division of Pediatrics, Oita Prefectural Hospital, Oita \\ ${ }^{3}$ Department of Pediatrics, Kyushu University, Fukuoka, Japan \\ (Received: July 19, 1991) \\ (Accepted: December 9, 1991)
}

Key words: exanthem subitum, acute encephalopathy, human herpesvirus-6

\section{Introduction}

Exanthem subitum is a common benign infectious disease of infancy characterized by high fever persisting for three or four days associated with a paucity of physical findings. The temperature falls to normal by crisis coincidental with the appearance of a morbilliform rash which fades within two days. Occasionally, the disease is ushered in by a convulsion.

Human herpesvirus-6 (HHV-6) was identified as a causative agent for the disease ${ }^{1)}$. Although exanthem subitum is generally considered benign disease, cases of encephalopathy or encephalitis following it have been reported ${ }^{2,3)}$.

We report a patient with exanthem subitum and subsequent encephalopathy, who showed seroconversion against HHV-6.

\section{Case Report}

A 6-month-old girl had convulsions and disturbance of consciousness following an episode of exanthem subitum. She was born at full term and had no medical problems during her prenatal and neonatal periods. There was no history of convulsions or neuromuscular disorders in her family.

She was admitted to our hospital for treatment of bronchial asthma and became well after intravenous administration of aminophylline. On the second hospital day, she developed fever and had loose bowel movements. The fever subsided on the 6th hospital day, at which time a maculopapular rash appeared on her trunk and she appeared clinically improved. She was diagnosed as having exanthem subitum. At midnight of the 6th hospital day, generalized convulsions suddenly developed, associated with vomiting and loss of consciousness. Convulsions continued for 2 hours and were controlled with intravenous diazepam. An arterial blood gas analysis revealed severe hypoxemia with respiratory and metabolic acidosis. An intratracheal tube was inserted and assisted mechanical ventilation was begun. A lumbar puncture yielded clear spinal fluid under the initial pressure of $200 \mathrm{~mm}$.

Laboratory examinations revealed a white blood cell count of 7,200 per $\mathrm{cmm}$. CRP was negative. Total protein was $5.1 \mathrm{~g} / \mathrm{dl}$, total bilirubin $0.18 \mathrm{mg} / \mathrm{dl}$, GOT $61 \mathrm{IU} / \mathrm{L}$, GPT $25 \mathrm{IU} / \mathrm{L}, \mathrm{LDH} 862 \mathrm{IU} / \mathrm{L}$, blood anmonia $65 \mu \mathrm{g} / \mathrm{dl}$, blood glucose $114 \mathrm{mg} / \mathrm{dl}$, ùric acid $8.1 \mathrm{mg} / \mathrm{dl}$ and calcium was $7.5 \mathrm{mg} / \mathrm{dl}$. Serum concentration of

\footnotetext{
別刷請求先：（广329-04）栃木県河内郡南河内町薬師

寺3311-1

自治医大小児科佐藤 隆美
} 
Fig. 1 Clinical course of the case.

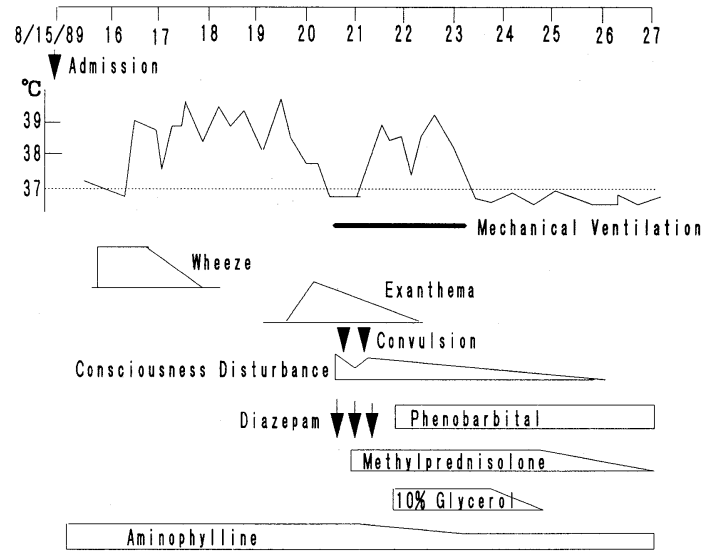

aminophylline was $21.0 \mu \mathrm{g} / \mathrm{ml}$. Cereblospinal fluid showed no elevation of cell count and protein concentration.

Methyl-prednisolone was administered for the prevention of brain edema. The level of her consciousness was slightly improved on the following day, but generalized convulsions developed again 24 hours after the first attack. The convulsions were controlled with diazepam and phenobarbital. Intravenous drip infusion of $10 \%$ glycerol was started for prevention of increase of intracranial pressure. Electroencephalogram showed diffuse, irregular theta waves with high voltage delta wave discharge, being compatible with Lovejoy's grade 2 coma. CT scan films revealed no obvious brain edema or regions of low density.

During the next two days, her general condition continued stable. Mechanical ventilation was discontinued on the 9 th hospital day. Level of her consciousness improved gradually and she began to take milk on the 10th hospital day (Fig. 1). She became well and was discharged on the 23rd hospital day without any neurological impairment. On her first birthday, she was able to walk without support and her neurological development was normal.

IgG HHV-6 antibody was evaluated using the indirect immunofluorescence method ${ }^{1,4)}$. MT-4 cells infected with the HHV-6 MA strain, isolated from infants with exanthem subitum by Yamanishi et al. ${ }^{1)}$ were used as the antigen. Serum IgG HHV-6 titer was less than 1:10 on the day of the first episode of convulsion, and was elevated to 1:320 two weeks later. IgG HHV-6 titer of the cerebrospinal fluid was less than 1:10 on the day of convulsion and 1:40 two weeks later. Antibody reactive with EB virus and cytomegalvirus were not elevated on serial examinations.

\section{Discussion}

Human herpesvirus- 6 was originally isolated from the blood of patients with acquired immunodeficiency syndrome and other hematologic disorders ${ }^{5}$. It has recently been isolated from normal adult and children with exanthem subitum ${ }^{1)}$. The virus is considerd a causative agent of several diseases, such as exanthem subitum ${ }^{1)}$, subacute necrotizing lymphadenitis ${ }^{7}$. It may also be related to rejection of transplanted kidneys ${ }^{8)}$ and hepatitis ${ }^{9)}$.

It is known that acute encephalitis or encephalopathy is one of the rare complications of exanthem subitum. Recently Ishiguro et al. ${ }^{10}$ ) reported the first case of exanthema subitum with acute encephalitis who showed the seroconversion against HHV-6. Our case seemed to be the second one to which HHV-6 was estimated to be the causative agent. There are several possible causes for convulsions and consciousness disturbance. The first episode of epilepsy may explain the convulsive state in this patient, but we could not 
locate a focus of epileptic discharge on serial EEG studies. Another disease which may explain the general convulsion in this case is mitochondrial encephalomyopathy in infants. Although follow-up of the case is necessary, it is not typical for the mitochondrial encephalomyopathy to have high fever and high intracranial pressure. Acute aminophylline intoxication was thought to be the possible explanation for the convulsions, but we have never been able to find a report of convulsion induced by aminophylline of which blood concentration is below $25 \mu \mathrm{g} / \mathrm{ml}$. Although there were no findings of brain edema on CT scan examinations, it is reasonable to consider convulsions, consciousness disturbance, elevated intracranial pressure and fever as symptoms of acute encephalopathy following exanthem subitum, to which HHV-6 was suspected to be the causative agent.

Ishiguro et al. ${ }^{10)}$ reported that the IgG index for HHV-6 was increased in cereblospinal fluid and suggested that HHV-6 might cause acute encephalitis. The clinical course of our case is similar to that of Ishiguro's case. It is well known that the patients who have exanthem subitum is likely to have an episode of febrile convulsion and show the bulging of anterior fontanel ${ }^{11}$. Some kind of interaction may exist between HHV-6 and central nervous system. Further study is necessary to investigate the affinity of HHV- 6 to the central nervous system of infants.

\section{References}

1) Yamanishi, K., Okuno, T., Shiraki, K., Takahashi, M., Kondo, T., Asano, Y. \& Kurata, T.: Identification of human herpesvirus-6 as a causal agent for exanthema subitum. Lancet 1: 1065-1067, 1988.

2) Burnstine, R.C., Kingstom, N. \& Paine R.S: Residual encephalopathy following roseola infantum. Am. J. Dis. Child. 98: 144-152, 1959.

3) Rosenblum, J.: Roseola infantum (exanthema subitum) complicated by hemiplegia. Am. J. Dis. Child. 69: 234-236, 1945.

4) Ueda, K., Kusuhara, K., Hirose, M., Okada, K., Miyazaki, C. \& Tokugawa, K.: Exanthema subitum and antibody to human herpesvirus-6. J. Infect. Dis. 159: 750-752, 1989.

5) Salahuddin, Z.S., Ablashi, D.V., Markham, P.D., Josephs, S.F., Sturzenegger, S., Kaplan, M., Halligan, G., Biberfeld, P., Wong-Staal, F., Kramsrsky, B. \& Gallo, R.C.: Isolation of a new virus, HBLV, in patients with lymphoproliferative disorders. Science. 234: 596-601, 1986.

6) Lopez, C, Pellett, P., Stewart, J., Goldsmith, C, Sanderlin, K., Black, J., Warfield, D. \& Feorino, P.: Characteristics of human herpesvirus-6. J. Infec. Dis. 157: 1271-1273, 1988.

7) Kirchesch, H., Mertens, T., Burkhardt, U., Kruppenbacher, J.P., Hoffken, A. \& Eggers, J.: Seroconversion against human herpesvirus-6 (and other herpesviruses) and clinical illness. Lancet. 2: 273-274, 1988.

8) Okuno, T., Higashi, K., Shiraki, K., Yamanishi, K., Takahashi, M., Kokado, Y., Ishibashi, M., Takahara, S., Sonodo, T., Tanaka, K., Baba, K., Yabuuchi, H. \& Kurata, T.: Human herpesvirus-6 infection in renal transplantation. Transplantation. 49: 519-522, 1990.

9) Dubedat, S. \& Kappagoda, N.: Hepatitis due to human herpesvirus-6. Lancet. 2: 1463-1464, 1989.

10) Ishiguro, N., Yamada, S. \& Takahashi, T.: A case of encephalitis following exanthema subitum caused by human herpesvirus-6. Pediatr. Jpn. 31: 727-731, 1990.

11) Moller, K.L.: Exanthema subitum and febrile convulsion. Acta. Pediat. 45: 534-540, 1956. 
Human Herpesvirus-6が原因と考えられた突発性発疹に 急性脳症を併発した 1 女児例

\author{
自治医科大学小児科 \\ 佐 藤 隆 美 \\ 大分県立病院小児科 \\ 井上敏 郎梶 原 真人 \\ 九州大学小児科 \\ 宮崎 千明楠浩一植田浩司 \\ (平成 3 年 7 月 19 日受付) \\ (平成 3 年 12 月 9 日受理)
}

要旨

Human Herpesvirus-6 (HHV-6) が原因と考学 られる突発性発疹の回復期に突然のけいれんで発 症した急性脳症の 6 カ月女児例を報告した。患児 は，3 日間におよぶ高熱の後, 全身性発疹が出現 し解熱, 突発性発疹と診断されたが, 解熱した夜, 再度の発熱, けいれん, 意識障害が突然出現し,
諸検査により急性脳症が疑われた，経過中，一時 的に全身状態の悪化を認め, 人工呼吸器による呼 吸管理，抗けいれん剤の投与などを要したが，重 篤な後遺症を残すことなく, 回復した。血清 HHV-6抗体価が回復期に上昇し，HHV-6による 急性脳症が疑われた。 